\title{
ARiBo pull-down for riboproteomic studies based on label-free quantitative mass spectrometry
}

\author{
GENEVIÈVE DI TOMASSO, ${ }^{1}$ LISA M. MILLER JENKINS, ${ }^{2}$ and PASCALE LEGAULT ${ }^{1}$ \\ ${ }^{1}$ Département de biochimie et médecine moléculaire, Université de Montréal, Succursale Centre-Ville, Montréal, Québec H3C 3J7, Canada \\ ${ }^{2}$ Laboratory of Cell Biology, National Cancer Institute, Bethesda, Maryland 20892, USA
}

\begin{abstract}
As part of their normal life cycle, most RNA molecules associate with several proteins that direct their fate and regulate their function. Here, we describe a novel method for identifying proteins that associate with a target RNA. The procedure is based on the ARiBo method for affinity purification of RNA, which was originally developed to quickly purify RNA with high yields and purity under native conditions. The ARiBo method was further optimized using in vitro transcribed RNA to capture RNAassociating proteins from cellular extracts with high yields and low background protein contamination. For these RNA pulldowns, stem-loops present in the immature forms of let-7 miRNAs (miRNA stem-loops) were used as the target RNAs. Labelfree quantitative mass spectrometry analysis allowed for the reliable identification of proteins that are specific to the stemloops present in the immature forms of two miRNAs, let-7a-1 and let-7g. Several proteins known to bind immature forms of these let-7 miRNAs were identified, but with an improved coverage compared to previous studies. In addition, several novel proteins were identified that better define the protein interactome of the let-7 miRNA stem-loops and further link let-7 biogenesis to important biological processes such as development and tumorigenesis. Thus, combining the ARiBo pull-down method with label-free quantitative mass spectrometry provides an effective proteomic approach for identification of proteins that associate with a target RNA.
\end{abstract}

Keywords: RNA pull-down; proteomics; RNA-protein interactions; pre-miRNA; let-7 biogenesis

\section{INTRODUCTION}

RNA molecules associate with proteins to regulate many biological processes, and the identification and characterization of ribonucleoprotein complexes is currently an area of intense scientific interest. For profiling interaction partners of macromolecules of interest, affinity purification coupled to mass spectrometry (AP-MS) has become a standard method. Until recently, the majority of efforts for characterizing interactions of RNA-protein networks by AP-MS have focused on isolating complexes using affinity-tagged proteins (Oeffinger 2012; Faoro and Ataide 2014; McHugh et al. 2014). However, there is also a need to characterize RNA-protein networks from the vantage point of the RNA, and a few strategies have been developed to purify RNA-protein complexes using affinity-tagged RNAs. Although most of these AP-MS investigations using tagged RNAs are based on in vitro assembly with proteins from cellular extracts, the characterization of RNA-protein complexes formed in vivo has also been investigated (Hogg and Collins 2007a,b; Vasudevan and Steitz 2007; Said et al. 2009; Baltz et al. 2012; Castello et al. 2012;

Corresponding author: pascale.legault@umontreal.ca

Article published online ahead of print. Article and publication date are at http://www.rnajournal.org/cgi/doi/10.1261/rna.057513.116. Freely available online through the RNA Open Access option.
Oeffinger 2012; Kwon et al. 2013; Faoro and Ataide 2014; Gerstberger et al. 2014; Kotzer-Nevo et al. 2014; Leppek and Stoecklin 2014; McHugh et al. 2014; Beckmann et al. 2015; Dong et al. 2015). Despite these efforts, there is still much that remains to be learned about the protein-interaction networks of specific RNAs.

Quantitative approaches in AP-MS studies are very powerful for the comprehensive and reliable identification of molecular interaction partners. Although the SILAC (stable isotope labeling by amino acids in cell culture) metabolic labeling approach has contributed significantly to the identification of interaction partners for specific proteins and RNAs as part of MS-based quantitative proteomics studies (Chen et al. 2015), label-free methods are becoming increasingly popular because they are usually simpler and cheaper (Tate et al. 2013; Sandin et al. 2014). Moreover, the recent development of high-resolution liquid chromatography coupled with tandem mass spectrometry methods (LC-MS/MS) allows label-free quantification with high accuracy and reproducibility (Skarra et al. 2011; Choi et al. 2012; Cox et al. 2014; Teo et al. 2014). When coupled with robust quantitative

(C) 2016 Di Tomasso et al. This article, published in RNA, is available under a Creative Commons License (Attribution-NonCommercial 4.0 International), as described at http://creativecommons.org/licenses/by-nc/4.0/. 
methods for data analysis, label-free AP-MS methods allow for the possibility to computationally remove nonspecific background interactions using a negative control, such as an RNA pull-down performed with a variant form of the target RNA.

Several affinity tags can be attached to an RNA of interest for its purification with associated proteins, and they include biotin, fluorophores, RNA aptamers that bind small molecules, and RNA recognition elements of proteins or protein domains. The RNA-based tags are particularly attractive for AP-MS applications given their suitability for purification under native conditions in both in vitro and in vivo applications (Srisawat and Engelke 2002; Oeffinger 2012; Faoro and Ataide 2014; McHugh et al. 2014; Panchapakesan et al. 2015). Commonly used RNA-based tags for AP-MS studies include streptavidin and tobramycin aptamers (Hartmuth et al. 2002; Hogg and Collins 2007b; Nelson et al. 2007; Butter et al. 2009; Leppek and Stoecklin 2014), as well as pp7 and MS2 RNA hairpins (Hogg and Collins 2007b; Nelson et al. 2007; Said et al. 2009; Slobodin and Gerst 2010). Some of these tags have been combined for tandem affinity purification in order to increase the purity of the isolated macromolecular complexes and reduce nonspecific interactions (Hogg and Collins 2007b; Nelson et al. 2007). However, it has become clear that these multistep affinity purification protocols may lead to dissociation of weak and/or transient interactors, which would significantly reduce the number of interactors identified. Thus, there is considerable interest in developing quick single-step affinity purification protocols that maximize the capture of true interaction partners and minimize nonspecific interactions (Oeffinger 2012; Faoro and Ataide 2014; McHugh et al. 2014). Moreover, given that only a few studies have combined RNA pull-down with quantitative MS (Butter et al. 2009; Lee et al. 2013; Adachi et al. 2014; Leppek and Stoecklin 2014), there is a need to develop robust RNA affinity purification procedures that can complement recent developments in label-free quantitative proteomics (Oeffinger 2012; Faoro and Ataide 2014; McHugh et al. 2014).

Over the past few years, our laboratory has optimized the ARiBo procedure for affinity purification of in vitro synthesized RNAs with a $3^{\prime}$-ARiBo tag, which contains an Activatable $g \operatorname{lm} S$ Ribozyme and the $\underline{B}$ oxB RNA from bacteriophage $\lambda$ (Di Tomasso et al. 2011, 2012a,b). The $\lambda$ boxB RNA part allows the specific immobilization of an ARiBo-tagged RNA on Glutathione-Sepharose (GSH-Sepharose) resin via its high affinity to the $\lambda N$-glutathione-S-transferase (GST) fusion protein, whereas the glmS ribozyme part can be activated by glucosamine-6-phosphate (GlcN6P) to liberate the RNA of interest and concomitantly produce a homogeneous $3^{\prime}$-end. Importantly, our ARiBo procedure rapidly generates highly pure RNA with very good yields under native conditions. Moreover, we have demonstrated that this procedure can be used to purify RNA with different sequences, secondary structures and sizes. In addition, it can be combined with complementary approaches to ensure $5^{\prime}$-homogeneity of the purified RNA (Salvail-Lacoste et al. 2013; Di Tomasso et al. 2014). Thus, the ARiBo procedure represents an attractive method for the purification of RNA-protein complexes in RNA-based AP-MS studies.

In this manuscript, we have optimized the ARiBo affinity purification method for riboproteomic studies based on label-free quantitative mass spectrometry. The RNA pulldown procedure was developed using in vitro transcribed ARiBo-tagged stem-loops present in the immature forms of miRNAs (miRNA stem-loops) to capture RNA-associating proteins from whole cell extracts (WCEs). Stem-loops derived from the precursors of let-7a-1 and let-7g were used (Bussing et al. 2008; Roush and Slack 2008; Viswanathan and Daley 2010; Thornton and Gregory 2012; Nguyen and Zhu 2015; Rehfeld et al. 2015), since several proteomic studies have been reported for these RNAs (Heo et al. 2008, 2009; Michlewski et al. 2008; Viswanathan et al. 2008; Michlewski and Caceres 2010; Chang et al. 2013; Lee et al. 2013). In addition, let-7a-1 and let-7g are two of the 12 human let-7 miRNAs that play important roles in mammalian development, metabolism, and cancer (Bussing et al. 2008; Roush and Slack 2008; Viswanathan and Daley 2010; Thornton and Gregory 2012; Nguyen and Zhu 2015; Rehfeld et al. 2015), and there is still significant interest in identifying proteins that control biogenesis of these miRNAs though interactions with the stem-loop structures present in their immature forms. We performed quantitative LC-MS/MS of RNA pull-downs using biological triplicates and two experimental controls to identify proteins that specifically bind to the stem-loops of let-7a-1 and let-7g. Several proteins were identified that were previously shown to bind immature forms of let-7 miRNAs (Heo et al. 2008, 2009; Michlewski et al. 2008; Viswanathan et al. 2008; Michlewski and Caceres 2010; Chang et al. 2013; Lee et al. 2013). In addition, we identified an extensive group of novel protein factors not previously found to bind these RNAs. Taken together, our results make an important contribution to defining the protein interactome of let-7 miRNA stemloops. In addition, they demonstrate that combining the ARiBo pull-down with label-free quantitative MS represents a powerful approach for the identification of proteins that associate with a target RNA.

\section{RESULTS}

\section{Optimization of the RNA pull-down assay}

The ARiBo procedure for affinity purification of RNA was adapted to isolate proteins from cell extracts that specifically associate with a target RNA (Fig. 1). The initial target RNA that we tested was SL-let-7g, the stem-loop structure found in the immature forms of the let-7g miRNA (Fig. 2). The SL-let-7g RNA was first synthesized by in vitro transcription with an ARiBo tag at its $3^{\prime}$-end (Di Tomasso et al. 2011). The ARiBo-tagged SL-let-7g was then bound to the $\lambda \mathrm{N}$-GST 
A

In vitro transcription of ARiBo-tagged RNA

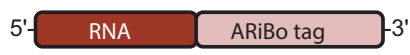

$\checkmark$
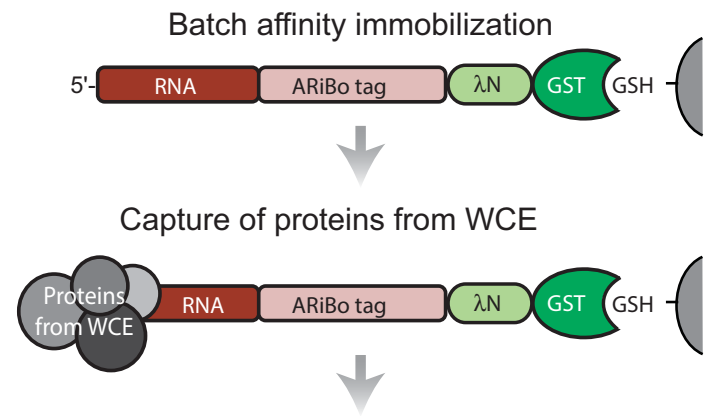

Self-cleavage with GlcN6P for elution of RNA and associated proteins

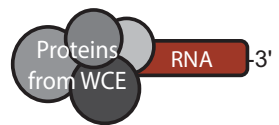

B

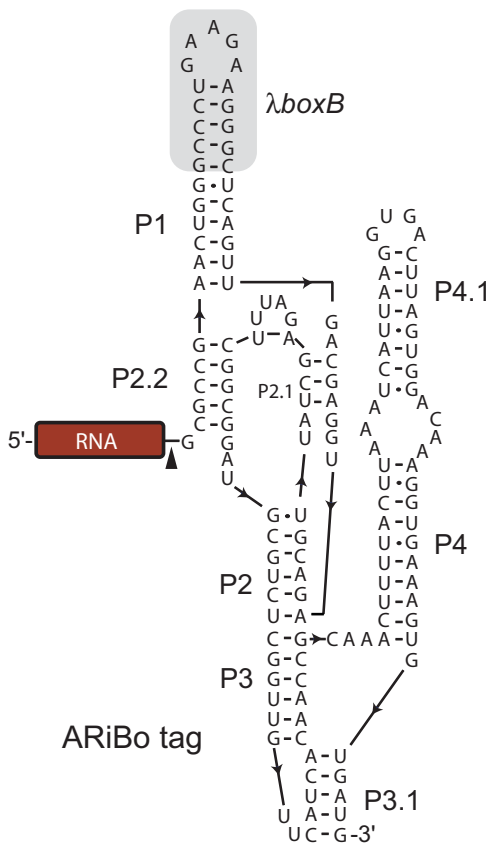

FIGURE 1. ARiBo pull-down method for the affinity capture of RNA-protein complexes. (A) General scheme for isolating RNA-associating proteins from a WCE by RNA pull-down with an ARiBo tag. (B) Schematics of the ARiBo-tagged RNA showing the sequence and secondary structure of the ARiBo tag used in this study with annotation of the paired regions (Salvail-Lacoste et al. 2013). The ARiBo tag contains the glmS ribozyme from Bacillus anthracis, which was modified to incorporate the $\lambda B o x B$ RNA (gray shading) in its variable P1 stem and stabilize the P2 stem. The black arrowhead identifies the site of ribozyme-mediated cleavage.

fusion protein $\left(\lambda \mathrm{N}^{+}-\mathrm{L}^{+}-\mathrm{GST}\right.$ from Di Tomasso et al. [2011]), and the resulting complex was immobilized on GSHSepharose resin. The bound RNA was incubated with a whole cell extract (WCE) from NT2 cells to allow formation of RNA-protein complexes. The NT2 cells were selected for these studies because they are widely used human pluripotent cells that express the two Lin28 homologs (Lin28A and Lin28B) endogenously, and these proteins are known pluripotent factors that regulate let-7 biogenesis through specific interactions with the stem-loop of immature forms of let-7 miRNAs (Piskounova et al. 2008; Desjardins et al. 2011, 2014; Triboulet et al. 2015). Following a wash step to remove nonspecifically bound proteins, the RNA and its associated proteins were eluted by addition of GlcN6P, which activates self-cleavage of the $g l m S$ ribozyme within the ARiBo tag. Importantly, incubation with a cell extract did not disrupt the chemical stability of the RNA, its immobilization on the GSH-Sepharose, or its elution with GlcN6P (Fig. 3A), which was verified by comparing to an ARiBo affinity purification performed in the absence of a cell extract (Fig. 3B). To evaluate the specificity of the RNA pull-downs, we compared the protein elution profile from the purification with the ARiBo-tagged SL-let-7g to that of a mock purification performed with the ARiBo tag only. Remarkably, several proteins were eluted in high abundance that specifically bound to the ARiBo-tagged SL-let-7g, whereas much lower levels of proteins were eluted from the mock purification (Fig.
4A). Given that let-7 stem-loops are known to directly bind to the Lin28A protein (Piskounova et al. 2008; Desjardins et al. 2011, 2014), we used Western blotting with an anti-Lin28A antibody to assess the specificity of the RNA pull-down (Fig. 4B). We confirmed by Western blot analysis of several biological replicates that the Lin28A protein specifically associates with the ARiBo-tagged SL-let-7g (Fig. 4C) in comparison with the ARiBo tag control. Given that the Lin28A protein binds with high affinity to pre-let$7 \mathrm{~g}\left(K_{\mathrm{d}}\right.$ of $\left.0.15 \mathrm{nM}\right)$ but also binds with lower affinity and specificity to other RNA sequences (Piskounova et al. 2008; Desjardins et al. 2011, 2014), the low levels of Lin28A in the mock pull-downs relative to the SL-let-7g pull-downs validate the specificity of the procedure.

The conditions of the RNA pull-down assays reported in Figure 4 were optimized to maximize the total amount of proteins eluted from the target RNA sample while reducing the total amount of proteins eluted from the ARiBo tag control (mock; Fig. 4A). Thus, these conditions contribute to discriminate true protein interactors from nonspecific background contaminants. We determined that salt concentrations of $5-10 \mathrm{mM} \mathrm{MgCl}_{2}$ and $100-250 \mathrm{mM} \mathrm{NaCl}$ are optimal in the load and wash buffers. In addition, we found that following incubation with the cell extract at least one wash step is necessary to reduce nonspecific binding. Subsequent wash steps are not desirable as they significantly reduced the total amount of protein in the RNA pull-downs, 


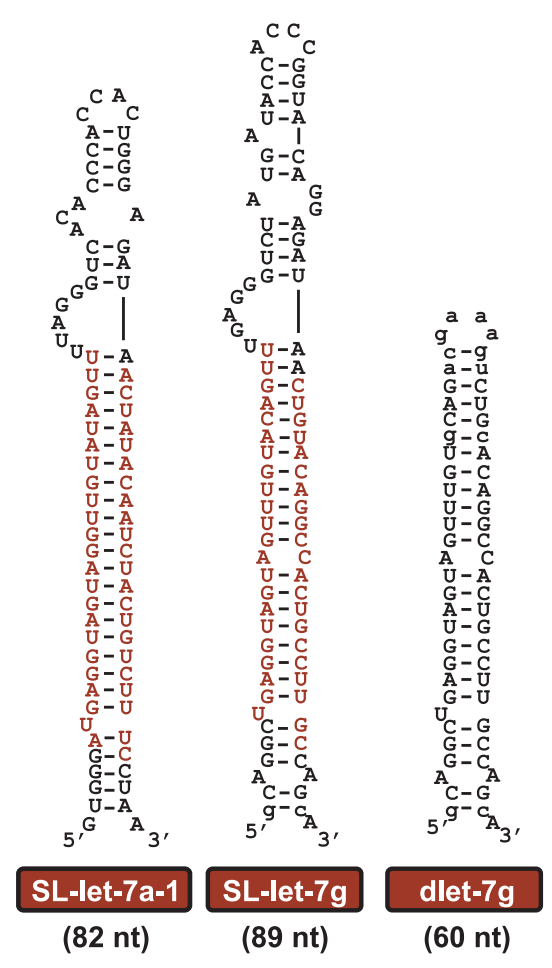

FIGURE 2. Sequence and putative secondary structures of two human miRNA stem-loops from the let-7 family (SL-let-7a-1 and SL-let-7g) and a control (dlet-7g) that only contains the RNA duplex portion of the SL-let-7g RNA (Desjardins et al. 2011). Residues that are part of the mature miRNAs are labeled in red within SL-let-7a-1 and SL-let$7 \mathrm{~g}$. Uppercase and lowercase letters indicate residues that are, respectively, present and not present in the natural RNAs.

thus the first wash was followed by a short 10 -sec rinse. Since longer incubation times (15-60 $\mathrm{min}$ ) with the WCE did not change the results, the shortest incubation time (15 $\mathrm{min}$ ) was selected to help reduce the total processing time between the addition of the WCE and the first RNA elution ( $20 \mathrm{~min}$ ). The amount of cell extract used for the RNA pull-down assay was found to be very critical. Using $3.5 \mathrm{nmol}$ of SL-let-7g, the addition of $\sim 300 \mu \mathrm{g}$ WCE in a final volume of $400 \mu \mathrm{L}$ was optimal with both NT2 and P19 (mouse embryonal carcinoma; not shown) cells. However, it may be important to adjust the amount of WCE when using either other target RNAs or other cell types. Finally, the spin-cup purification method was found to be one of the most important factors for maximizing the abundance of protein interactors in the SL-let-7g RNA pull-down while minimizing the level of background binding in the mock pull-down. In this respect, the spincup purification method was found to be more efficient than the standard batch method, in addition to being faster and more convenient. Although the use of magnetic resin has been previously reported to improve the specificity of RNA pull-downs (Oeffinger 2012), we observed an increase in background binding with the use of magnetic beads (MagneGST, Promega; results not shown) in comparison with the use of nonmagnetic beads retained by spin cups.

\section{Label-free quantitative mass spectrometry}

For our riboproteomics studies, RNA pull-downs were performed in biological triplicate with two ARiBo-tagged miRNA stem-loops of the let-7 family, SL-let-7a-1 and SLlet-7g, as well as with two experimental controls, the ARiBo tag alone (mock) and an ARiBo-tagged SL-let-7g variant that retains the duplex region but not the terminal loop (dlet-7g; Fig. 2; Desjardins et al. 2011). The general scheme used for label-free quantitative MS of ARiBo pull-downs is illustrated in Figure 5. Briefly, the sample and control RNA pull-down assays are performed independently with the same NT2 WCE preparation, and the tryptic digests of the eluted samples are analyzed by nano-liquid chromatography coupled with tandem mass-spectrometry (nano-LC-MS/ MS). For each ARIBo pull-down, the spectral counts for each protein identified were analyzed using SAINT (Significance Analysis of INTeractome), an algorithm that provides probabilistic scoring of AP-MS data analysis and has been successfully adopted in several studies (Breitkreutz et al. 2010; Skarra et al. 2011; Oeffinger 2012; Tate et al. 2013). The SAINT analysis takes into account data from biological replicates as well as from negative control purifications (Teo et al. 2014). Here, the SAINTexpress scores were computed based on spectral counts of the three individual replicates using either the mock purification ( $S_{\text {mock }}$ score) or the dlet-7g purification $\left(S_{\text {dlet }}\right.$ score $)$ as the negative control. SAINT analysis led to the identification of several binding partners for the SL-let-7a-1 and SL-let-7g RNAs using $S_{\text {mock }}$ and $S_{\text {dlet }}$ scores $\geq 0.65$ (Table 1; Supplemental Tables S1, S2).

\section{Identification of several common protein interactors for SL-let-7a-1 and SL-let-7g}

Quantitative MS analysis allowed the identification of 86 and 50 proteins from the SL-let-7a-1 and SL-let-7g pull-downs, respectively. This includes a set of 42 proteins common to both SL-let-7 RNAs (Fig. 6A; Table 1; Supplemental Table S1). A small subset of these 42 proteins were selected for further validation by Western blot analysis, namely Nucleolin, IGF2BP1 and Lin28B, and confirmed their selective enrichment in the SL-let-7a-1 and SL-let-7g RNA pulldowns in comparison with a mock pull-down (Fig. 6B). Interestingly, these three proteins have been associated with cancer progression (Thornton and Gregory 2012; Bell et al. 2013; Pichiorri et al. 2013) and are known to bind RNA sequences that match homologous sequence elements of prelet-7 RNAs [5'-UUAGG-3' for Nucleolin (Ishikawa et al. 1993), 5'-(C/A)CA(C/U)-3' for IGF2BP1 (Patel et al. 2012) and $5^{\prime}$-GGAG-3' for Lin28B (Graf et al. 2013)], suggesting that they may regulate several members of the let-7 family.

Given that the human mRNA interactome comprises over 1200 RNA-binding proteins likely important for numerous aspects of RNA processing and function (Baltz et al. 2012; 


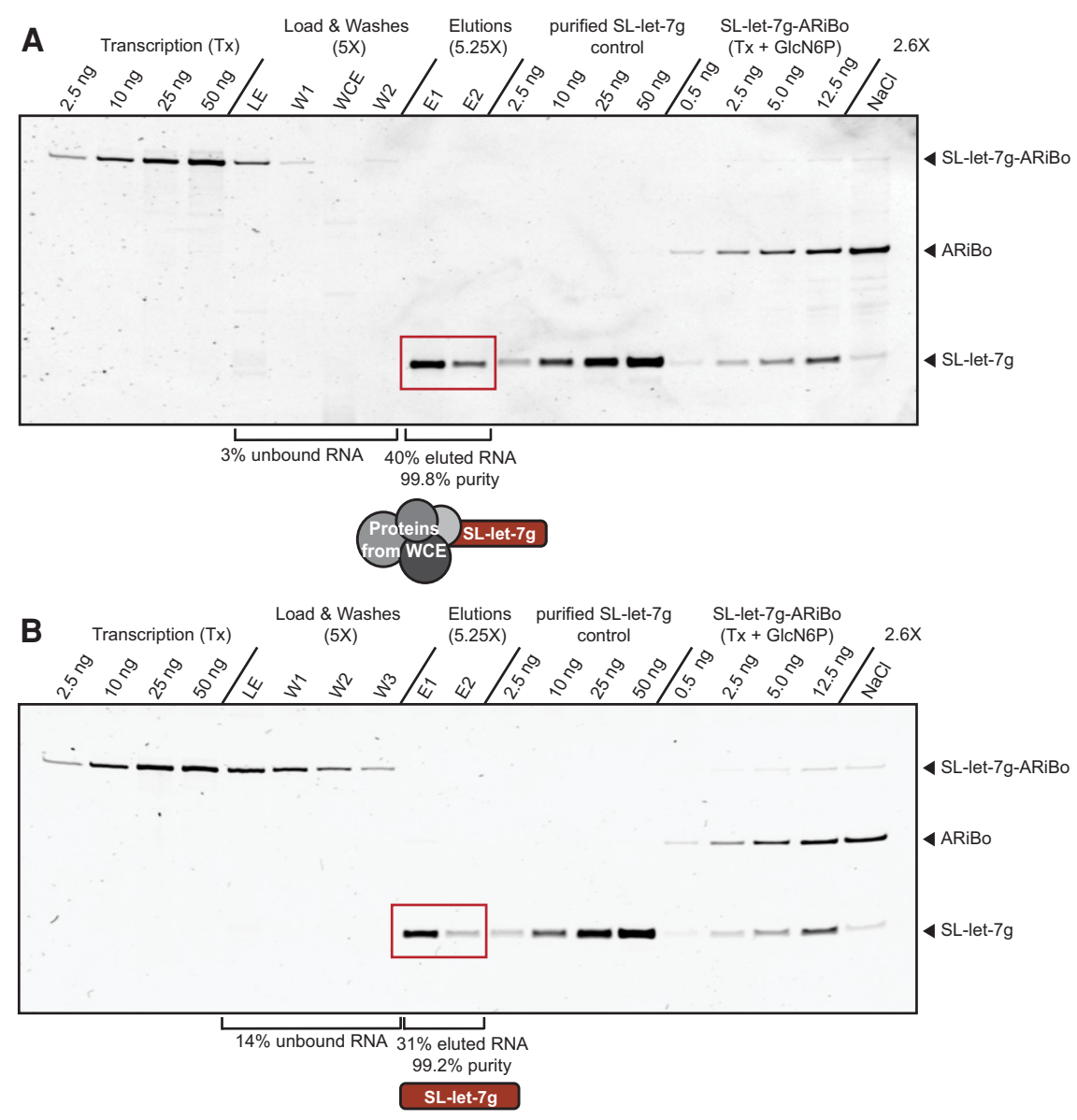

FIGURE 3. Affinity purification of SL-let-7g in either the presence or the absence of a WCE. Aliquots from the ARiBo purification either with $(A)$ or without $(B)$ incubation with an NT2 WCE are analyzed on SYBR-Gold stained 7-M urea PAGE gels (LE, loading eluate; W1-3, washes; WCE, NT2 WCE eluate; E1-2, RNA elutions; $\mathrm{NaCl}$, matrix regeneration with $2.5 \mathrm{M} \mathrm{NaCl}$ ) in amounts shown, where $1 \times$ corresponds to the volumes of affinity purification eluates (or washes) equivalent to a maximum of $50 \mathrm{ng}$ of ARiBo-tagged SL-let-7g from the transcription reaction or $19 \mathrm{ng}$ of SL-let-7g to be purified (Di Tomasso et al. 2011, 2012a). The protocols for the RNA pulldown and the RNA purification have been optimized such that for the RNA pull-down $(A)$, there is one wash after immobilization of the RNA on the resin (W1) and one wash after (W2) incubation with the NT2 WCE, whereas for the RNA purification $(B)$, there is a total of three washes (W1-3) after immobilization of the RNA on the resin (Di Tomasso et al. 2011, 2012a). In addition, standard amounts of ARiBo-tagged SL-let-7g from the transcription reaction, purified SLlet-7g and SL-let-7g resulting from addition of GlcN6P in the transcription reaction were loaded for quantitative analysis, as previously described (Di Tomasso et al. 2011, 2012a). The red box highlights the purified RNA.

Castello et al. 2012; Kwon et al. 2013; Gerstberger et al. 2014; Beckmann et al. 2015), it is not surprising that 83 of the 94 proteins identified from the SL-let-7a-1 and SL-let-7g pulldowns are known RNA-binding proteins. Several RNA-binding proteins have already been shown to regulate miRNA biogenesis, including ADAR, AGO, BCDIN3D, Dicer, DDX5, DDX17, DGCR8, Drosha, Exportin 5, hnRNP A1, ILF2, ILF3, KHSRP, LIN28A/B, Musashil, Nucleolin, PACT, SRFS3, TRBP and the Tutases TUT4 and TUT7 (for review, see Krol et al. 2010; Ha 2011; van Kouwenhove et al. 2011; Abdelmohsen et al. 2012; Kawahara et al. 2012; Connerty et al. 2015). Among these proteins, we identified DDX5,
ILF2, ILF3, LIN28B, and Nucleolin with both the SL-let-7a-1 and SL-let-7g RNAs, whereas hnRNP A1, ADAR, DDX17, PACT (PRKRA), and SRFS3 were specifically found with only one of the two RNAs. In contrast, the general miRNA-processing factors AGO, Dicer, DGCR8, Drosha, and Exportin 5 as well as the let-7 specific factors TUT4 and TUT7 were not identified, but this was to be expected given that they require additional recognition elements for binding than those present in the SL-let-7 RNAs (Ha 2011; Connerty et al. 2015), such as specific elements at the $5^{\prime}$ - and $3^{\prime}$-ends (e.g., $5^{\prime}$-monophosphate and $3^{\prime}$ $\mathrm{OH})$. Other proteins involved in miRNA biogenesis, such as Musashil (Kawahara et al. 2012), are missing from our analysis most likely due to our experimental conditions, particularly the specific cell type used for preparing the WCE and the type of miRNA stemloops tested. Surprisingly, Lin28A, which is present in the NT2 cell extract and was identified by Western blot analysis of SL-let-7g pull-downs (Fig. 4B,C), did not pass the cutoff to be considered an interactor of either SL-let-7 RNA in the MS analysis. Based on spectral counts, Lin28A was identified as a highly abundant protein in all RNA pull-downs reported in this study, including the control samples, but SAINTexpress scores of zero were obtained for the analysis of the SL-let-7a-1 and SL-let-7g RNA pulldowns (Supplemental Table S2). Thus, Lin28A is a false negative of the MS analysis likely due to the high abundance of Lin28A in NT2 cells and the ability of this protein to bind nonspecifically to RNA at high concentration. This result raises the possibility that there may be additional false negatives like Lin28A that are not identified in our AP-MS study due to the stringency of the MS analysis criteria.

Interestingly, seven proteins were identified in both the SLlet-7a-1 and SL-let-7g pull-downs when using the mock control but not when using the dlet-7g control (Table 1; Fig. 6). These results strongly indicate that these proteins specifically interact with the duplex region of these SL-let-7 RNAs. Although the RNA-binding properties of four of these seven proteins (HMGA1, TCOF1 associated with the Treacher Collins syndrome 1, SON, and HSPE1) have not been well characterized, the other three (STAU1, ILF2, and ILF3) are 

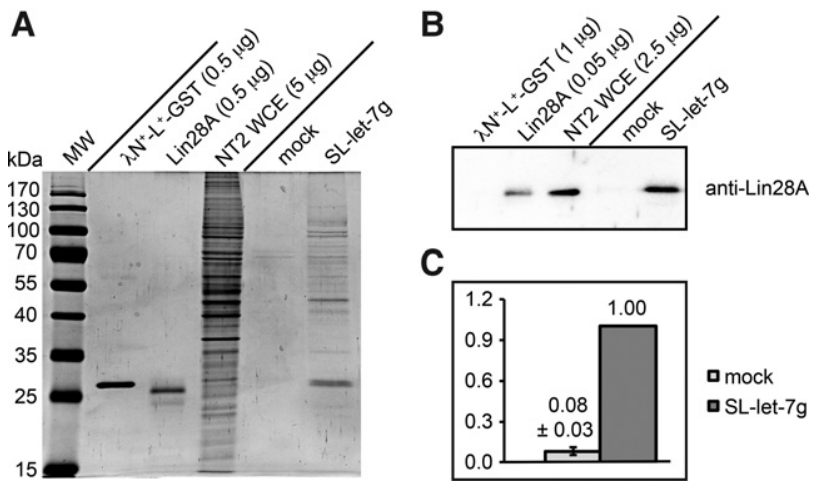

FIGURE 4. ARiBo pull-down with an NT2 WCE. (A) Aliquots of the elution fractions ( $90 \%$ of E1) from the RNA pull-downs of the ARiBo tag only (mock) and SL-let-7g-ARiBo (SL-let-7g) with an NT2 WCE analyzed on a Coomassie-stained SDS-PAGE gel. (B) Western blot with an anti-Lin28A antibody of the elution fractions (10\% of E1) from the mock and SL-let-7g pull-downs. The relative quantification of the anti-Lin28A antibody is provided in $C$ based on three biological replicates with the quantity of Lin28A from the SL-let-7g pull-down scaled to one and that of the mock pull-down provided as an average value with SD. In $A$ and $B$, control lanes are provided that contain purified proteins $\left(\lambda \mathrm{N}^{+}-\mathrm{L}^{+}\right.$-GST and Lin28A) and an NT2 WCE.

known double-stranded RNA-binding proteins (Satoh et al. 1999; Wickham et al. 1999). The ILF2 and ILF3 proteins form the ILF2-ILF3 heteromeric complex, also termed the NF45-NF90 complex, which has been shown to negatively regulate miRNA biogenesis (Sakamoto et al. 2009). To the best of our knowledge, STAU1, more commonly known as Staufen1, has not been directly implicated in miRNA biogenesis (Ren et al. 2016). However, genomewide analysis of Staufen1-associated mRNAs provides strong evidence that preferential Staufen 1 targets for in vivo binding are double-stranded regions that contain mismatches and/or unpaired bases (Kim et al. 2007; Laver et al. 2013), like those found in miRNA stem-loops.

\section{DISCUSSION}

Several proteomic studies have previously exploited AP-MS methodologies to identify proteins that interact with miRNAs stem-loops. However, among the 94 proteins identified in our riboproteomic analysis of the SL-let-7a-1 and SL-let-7g pull-downs, only 36 have been previously identified in proteomic studies with the same miRNA stem-loops (Supplemental Table S1). Moreover, among the 42 proteins that were identified in both the SL-let-7a-1 and SL-let$7 \mathrm{~g}$ pull-downs, only half have been previously identified in proteomic studies with the same miRNA stem-loops, including proteomic studies using the same NT2 cell line (Table 1). Therefore, our AP-MS method allows for the identification of several SL-let-7-associating proteins that were not previously identified and, given the stringency of the analysis, are likely to represent genuine interactors of let-7 miRNA stem-loops. Some of these newly identified SL-let-7 interactors are known to be involved in important biological processes, such as development and tumorigenesis. Interestingly, we find all three IGF2BP human paralogs, IGF2BP1, IGF2BP2, and IGF2BP3, which have been implicated in development, metabolic control and tumorigenesis and are known to direct mRNA stabilization, translation, and transport (Bell et al. 2013). Similarly, they could regulate miRNA biogenesis and transport of immature forms of miRNAs. We also identified five proteins, IGF2BP1, HNRNPU, SYNCRIP, YBX1, and DHX9, that constitute the coding region determinant (CRD)-mediated complex known to promote mRNA stability of the c-myc oncogene (Weidensdorfer et al. 2009), suggesting that the CRD-mediated complex could also play a role in stabilizing immature forms of miRNAs. Future studies are needed to validate that the proteins identified here directly bind to the SL-let-7a-1 and SL-let-7g RNAs in the absence of the ARiBo tag and to establish whether or not these proteins regulate miRNA biogenesis. In addition, it will be interesting to determine if these proteins interact with other miRNA stem-loops since only a handful of pre-miRNAs have been characterized by AP-MS to date.

As in other AP-MS studies, the use of a tag for affinity purification may prevent the binding of proteins that would

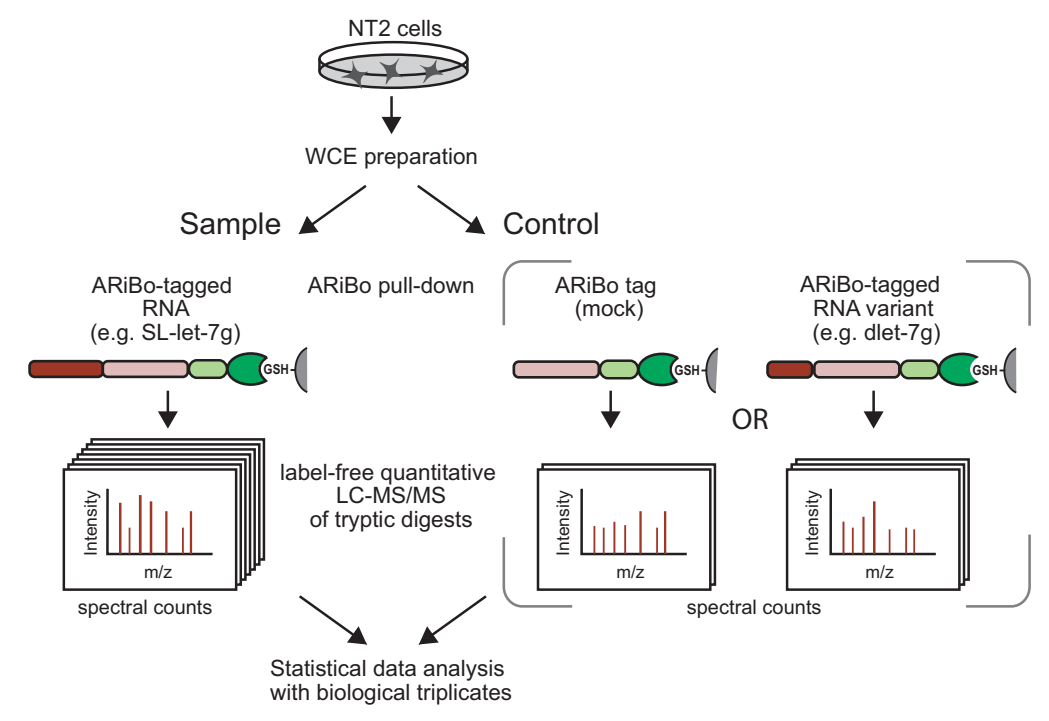

FIGURE 5. Flowchart for the label-free quantitative MS analysis of the protein interactome for a specific RNA using the ARiBo method. The ARiBo pull-downs are performed with an ARiBotagged RNA (sample) and two controls, the ARiBo tag (mock) and an ARiBo-tagged RNA variant (dlet-7g), using the same NT2 whole cell extract (WCE). The tryptic digests of these pull-downs are then analyzed by label-free quantitative LC-MS/MS. The statistical analysis of the MS data from biological triplicates (sample and controls) is performed based on spectral counts using either the mock control or the dlet-7g control. 
TABLE 1. Partial MS analysis results listing proteins identified in both the SL-let-7a-1 and the SL-let-7g ARiBo pull-downs

\begin{tabular}{|c|c|c|c|c|c|c|c|c|c|}
\hline \multirow[b]{2}{*}{ Gene name } & \multirow[b]{2}{*}{ Protein name } & \multirow[b]{2}{*}{ Uniprot entry } & \multicolumn{2}{|c|}{ SL-let-7a-1 } & \multicolumn{2}{|c|}{ SL-let-7g } & \multirow[b]{2}{*}{ RBP } & \multirow[b]{2}{*}{$7 a-1$} & \multirow[b]{2}{*}{$7 g$} \\
\hline & & & $\begin{array}{l}\text { Versus } \\
\text { Mock }\end{array}$ & $\begin{array}{l}\text { Versus } \\
\text { dlet-7g }\end{array}$ & $\begin{array}{l}\text { Versus } \\
\text { Mock }\end{array}$ & $\begin{array}{l}\text { Versus } \\
\text { dlet-7g }\end{array}$ & & & \\
\hline C7orf50 & Uncharacterized protein C7orf50 & Q9BRJ6 & 0 & 0 & 0 & 0 & - & & \\
\hline CSDAP1;YBX3 & Y-box-binding protein 3 & P16989 & 0 & O & 0 & 0 & $\bullet$ & 4 & \\
\hline CSNK2A1 & Casein kinase II subunit $\alpha$ & P68400 & 0 & 0 & 0 & 0 & & & \\
\hline DDX5 & Probable ATP-dependent RNA helicase DDX5 & P17844 & O & O & O & O & - & 3,4 & 6 \\
\hline DHX9 & ATP-dependent RNA helicase A & Q08211 & 0 & O & 0 & & $\bullet$ & $1,3,4,5$ & 6 \\
\hline GRSF1 & G-rich sequence factor 1 & Q12849 & 0 & 0 & 0 & & $\bullet$ & & \\
\hline HMGA1 & High-mobility group protein HMG-I/HMG-Y & P17096 & 0 & & 0 & & & & \\
\hline HNRNPAO & Heterogeneous nuclear ribonucleoprotein $\mathrm{AO}$ & Q13151 & 0 & O & 0 & & $\bullet$ & 1,3 & \\
\hline HNRNPA3 & Heterogeneous nuclear ribonucleoprotein A3 & P51991 & O & O & 0 & O & $\bullet$ & 3,4 & 6 \\
\hline HNRNPAB & Heterogeneous nuclear ribonucleoprotein $\mathrm{A} / \mathrm{B}$ & Q99729 & 0 & 0 & 0 & & - & 4 & 6 \\
\hline HNRNPD & Heterogeneous nuclear ribonucleoprotein D0 & Q14103 & 0 & 0 & 0 & & $\bullet$ & 3 & \\
\hline HNRNPU & Heterogeneous nuclear ribonucleoprotein $U$ & Q00839 & 0 & O & O & & $\bullet$ & 3,4 & 6 \\
\hline HNRNPUL1 & $\begin{array}{l}\text { Heterogeneous nuclear ribonucleoprotein } U \text { - } \\
\text { like protein } 1\end{array}$ & Q9BUJ2 & O & O & O & & $\bullet$ & 3,4 & 6 \\
\hline HSPE1 & $101 \mathrm{kDa}$ heat shock protein, mitochondrial & P61604 & 0 & & 0 & & $\bullet$ & & \\
\hline IGF2BP1 & $\begin{array}{l}\text { Insulin-like growth factor } 2 \text { mRNA-binding } \\
\text { protein } 1\end{array}$ & Q9NZI8 & O & O & O & ○ & $\bullet$ & 3,4 & 6 \\
\hline IGF2BP2 & $\begin{array}{l}\text { Insulin-like growth factor } 2 \text { mRNA-binding } \\
\text { protein } 2\end{array}$ & Q9Y6M1 & O & O & O & ○ & • & & \\
\hline IGF2BP3 & $\begin{array}{l}\text { Insulin-like growth factor } 2 \text { mRNA-binding } \\
\text { protein } 3\end{array}$ & O00425 & O & O & O & O & • & & \\
\hline ILF2 & Interleukin enhancer-binding factor 2 & Q12905 & 0 & & 0 & & - & $3,4,5$ & 6 \\
\hline ILF3 & Interleukin enhancer-binding factor 3 & Q12906 & 0 & & 0 & & $\bullet$ & $1,3,4,5$ & 6 \\
\hline LIN28B & Protein lin-28 homolog B & Q6ZN17 & O & O & O & O & $\bullet$ & 1,4 & 6 \\
\hline$N C L$ & Nucleolin & P19338 & O & O & O & O & - & $2,4,5$ & \\
\hline NONO & $\begin{array}{l}\text { Non-POU domain-containing octamer-binding } \\
\text { protein }\end{array}$ & Q15233 & O & O & O & O & - & 4 & 6 \\
\hline NSUN2 & tRNA [cytosine(34)-C(5)]-methyltransferase & Q08J23 & 0 & 0 & 0 & & - & & \\
\hline RPL22 & $60 S$ ribosomal protein L22 & P35268 & O & 0 & O & ○ & $\bullet$ & & \\
\hline RPS17;RPS17L & $40 \mathrm{~S}$ ribosomal protein S17 & P08708 & 0 & 0 & 0 & 0 & $\bullet$ & & \\
\hline RPS7 & $40 S$ ribosomal protein $\mathrm{S} 7$ & P62081 & 0 & O & 0 & O & - & & \\
\hline SON & Protein SON & P18583 & 0 & & 0 & & - & & \\
\hline SRP14 & Signal recognition particle $14 \mathrm{kDa}$ protein & P37108 & 0 & O & O & O & $\bullet$ & & \\
\hline SRSF1 & Serine/arginine-rich splicing factor 1 & Q07955 & 0 & 0 & 0 & 0 & $\bullet$ & 3 & \\
\hline SRSF9 & Serine/arginine-rich splicing factor 9 & Q13242 & O & O & ○ & ○ & - & & \\
\hline SSB & Lupus La protein & P05455 & 0 & 0 & 0 & & $\bullet$ & 3 & \\
\hline STAU1 & $\begin{array}{l}\text { Double-stranded RNA-binding protein Staufen } \\
\text { homolog } 1\end{array}$ & O95793 & O & & O & & $\bullet$ & 3,4 & \\
\hline STRBP & Spermatid perinuclear RNA-binding protein & Q96SI9 & O & ○ & O & ○ & $\bullet$ & 3,4 & \\
\hline SUB1 & $\begin{array}{l}\text { Activated RNA polymerase II transcriptional } \\
\text { coactivator p15 }\end{array}$ & P53999 & O & O & O & O & $\bullet$ & & \\
\hline SYNCRIP & Heterogeneous nuclear ribonucleoprotein Q & O60506 & O & O & 0 & O & - & & \\
\hline TCOF1 & Treacle protein & Q13428 & O & & O & & $\bullet$ & & \\
\hline TFAM & Transcription factor A, mitochondrial & Q00059 & 0 & 0 & 0 & 0 & $\bullet$ & & \\
\hline THOC4;ALYREF & THO complex subunit 4 & Q86V81 & O & ○ & O & O & $\bullet$ & & 6 \\
\hline TRMT61A & $\begin{array}{l}\text { tRNA [adenine(58)-N(1)]-methyltransferase } \\
\text { catalytic subunit }\end{array}$ & Q96FX7 & O & O & O & O & & & \\
\hline XRCC6 & X-ray repair cross-complementing protein 6 & P12956 & 0 & 0 & 0 & 0 & - & & \\
\hline YBX1 & Nuclease-sensitive element-binding protein 1 & P67809 & $-{ }^{\mathrm{a}}$ & 0 & $-{ }^{\mathrm{a}}$ & 0 & - & 4 & 6 \\
\hline ZC3HAV1 & Zinc finger $\mathrm{CCCH}$-type antiviral protein 1 & Q7Z2W4 & ○ & ○ & ○ & O & $\bullet$ & & \\
\hline
\end{tabular}

Positive identification of a protein interactor (open circle) from the SL-let-7a-1 and SL-let-7g pull-downs is based on a SAINTexpress score $\geq 0.65$. Results are listed using either the mock or the dlet-7g ARiBo pull-down as the negative control. RNA-binding proteins (RBPs; black dot) are inferred based on recent genome-wide AP-MS studies of mRNA-binding proteins (Baltz et al. 2012; Castello et al. 2012; Kwon et al. 2013; Beckmann et al. 2015). Results from previous AP-MS studies are provided for let-7a-1 stem-loops (7a-1; 1: WCE from Huh7 cells [Heo et al. 2008]; 2: with nuclear extract from HeLa cells [Michlewski et al. 2008; Michlewski and Caceres 2010]; 3: WCE from Lin28A-transfected HEK203T cells [Heo et al. 2009]; 4: WCE from P9 cells [Chang et al. 2013]; and 5: WCE from HeLa and NT2 cells [Lee et al. 2013]) and a let-7g stem-loop (7g; 6: with P19 cells [Viswanathan et al. 2008]).

${ }^{a}$ The SAINTexpress scores for the identification of the YBX1 protein from the SL-let-7a-1 and SL-let-7g pull-down versus the mock control are just below the cutoff $(0.65>$ score $\geq 0.60)$. 


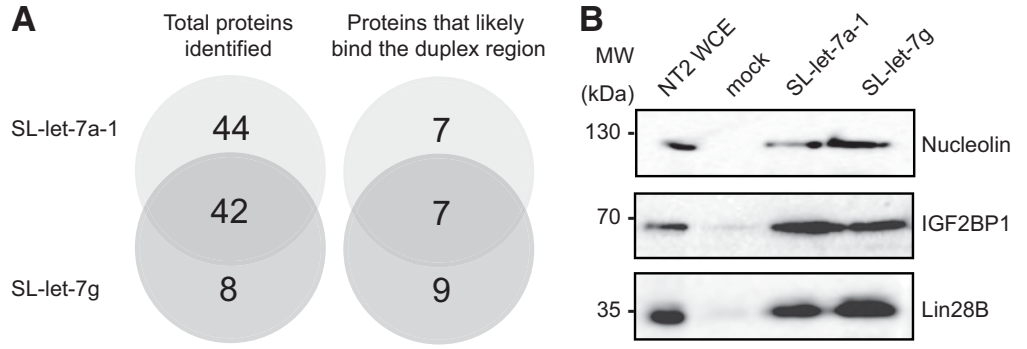

FIGURE 6. Summary and validation of the AP-MS results for SL-let-7a-1 and SL-let-7g. (A) The overlap of identified proteins in the SL-let-7a-1 and SL-let-7g ARiBo pull-downs is shown using Venn diagrams. The total proteins identified were taken from proteomic analysis using the mock and dlet-7g controls. The proteins that likely bind the duplex region are those identified using the mock control but not the dlet- $7 \mathrm{~g}$ control. $(B)$ Validation of the AP-MS results by Western blots of the elution fractions (50\% of E1) from the SL-let-7a-1, SL-let-7g, and mock pull-downs.

normally interact with the free target or, inversely, induce the binding of proteins that do not normally bind to the free target. In particular, a common concern when using an RNA tag is the possibility for interactions between the tag and the target RNA that would disrupt the folding of the target RNA. Using the activatable ARiBo tag, one can quickly verify that this tag does not induce significant misfolding of the target RNA. In the present study, this was done by testing the efficiency of cleavage of the ARiBo tag from the fusion RNAs in the presence of $1 \mathrm{mM}$ GlcN6P (lanes 15-18 in Fig. 3A,B). For both the SL-let-7a-1-ARiBo (not shown) and SL-let-7gARiBo (Fig. 3) fusion RNAs, efficient cleavage of the ARiBo tag was observed under these conditions, providing clear evidence that the ARiBo tag and target RNA fold independently of each other within the fusion RNAs.

Our AP-MS approach is particularly powerful given that the ARiBo pull-down significantly minimizes nonspecific binding (low protein levels in the mock control; Fig. 4A), and the MS analysis provides a stringent quantitative assessment of true protein interactors. The high sensitivity and specificity of the RNA pull-down results in part from the use of optimized conditions for the RNA pull-downs, including the amount of cell extract, buffer conditions, and elution conditions, but also depends on the use of spin-cup devices during the purification to efficiently wash protein contaminants without losing resin. The ARiBo tag itself contributes significantly to the high sensitivity and specificity of the RNA pulldown by affording high-affinity immobilization via the $\lambda$ boxB/N peptide complex ( $K_{\mathrm{d}}$ of $10 \mathrm{pM}$ ) (Austin et al. 2002; Di Tomasso et al. 2011) as well as highly efficient elution of the RNA-protein complex by activatable cleavage of the $g \operatorname{lm} S$ ribozyme. Similarly, activatable cleavage of an RNA tag has previously been exploited for AP-MS studies using the activatable Csy4 enzyme of a cognate RNA substrate tag, where it was shown to dramatically reduce the amount of background protein contaminants (Lee et al. 2013). In comparison to a noncleavable system, elution by cleavage of the target RNA from the immobilized tag prevents the elution of proteins that are bound to the tag and thus likely re- duces the amount of eluted proteins that are not specifically associated with the target RNA. Moreover, since cleavage of the ARiBo tag is activated by a small metabolite (Glc6NP), this prevents contamination of the eluate by a larger molecule that could potentially interfere with the MS analysis. An important advantage of the activatable $g l m S$ ribozyme compared to other cleavable tags is that efficient cleavage keeps the RNA elution period to a minimum (15 min) such that the RNA pull-down can be performed very quickly under conditions that help maintain the integrity of the RNA-protein complexes. Thus, the ARiBo pull-down procedure is also well suited for other applications, such as the purification of RNA-protein assemblies for biochemical and structural characterization. Since it can be performed quickly and efficiently, the ARiBo pull-down could also be used to streamline high-throughput isolation of proteins that associate with target RNAs.

In summary, combining the ARiBo pull-down method with label-free quantitative mass spectrometry has allowed us to better define the protein interactome of the stem-loops of two specific miRNAs, human let-7a-1 and let-7g. Our method is well suited to investigate the protein interactors of other interesting RNAs found in living cells so that we can better understand how these RNAs collaborate with proteins to sustain a wide range of biological processes.

\section{MATERIALS AND METHODS}

\section{Cell culture and whole cell extract (WCE) preparation}

The human pluripotent embryonal carcinoma cell line NTERA-2 cl. D1 (NT2; ATCC) was maintained in Dulbecco's modified Eagle's Medium (DMEM; Wisent) supplemented with 10\% (v/v) fetal bovine serum (FBS; Wisent) at $37^{\circ} \mathrm{C}$ and in $10 \% \mathrm{CO}_{2}$. NT2 cells grown to near confluency in $150-\mathrm{mm}$ Petri dishes were washed once with cold PBS (10 mM Na $2 \mathrm{HPO}_{4}, 2 \mathrm{mM} \mathrm{KH} \mathrm{HO}_{4}, 2.7 \mathrm{mM} \mathrm{KCl}$, and $140 \mathrm{mM} \mathrm{NaCl}$, adjusted to $\mathrm{pH}$ 7.4) and harvested by scraping. The resuspended cells were washed twice with cold PBS, and the cell debris removed by centrifugation. The pellet was incubated for 20 min on ice with WCE lysis buffer (50 mM HEPES [pH 7.5], 100 $\mathrm{mM} \mathrm{NaCl}, 1 \% \mathrm{NP}-40$ and $1 \mathrm{mM} \mathrm{DTT}$ ) supplemented with protease inhibitors ( $0.1 \mathrm{mM}$ AEBSF, $1 \mu \mathrm{g} / \mathrm{mL}$ aprotinin, $1 \mu \mathrm{M}$ pepstatin, and 1 $\mu \mathrm{g} / \mathrm{mL}$ leupeptin), vortexing every $5 \mathrm{~min}$. The cell lysate was then clarified by centrifugation for $10 \mathrm{~min}$ at $16,000 \mathrm{~g}$. The resulting WCE was snap frozen in a dry-ice/ethanol bath and kept at $-80^{\circ} \mathrm{C}$ until use. The protein concentration of the WCE was quantified with a Micro BCA protein assay kit (Pierce).

\section{Recombinant protein expression and purification}

Previously established procedures were employed for the expression and purification of the $\lambda \mathrm{N}^{+}-\mathrm{L}^{+}$-GST fusion protein (Di Tomasso 
et al. 2011, 2012b) and the human Lin28A protein (Desjardins et al. 2011).

\section{In vitro transcription of ARiBo-tagged RNAs and affinity purifications}

All plasmids for in vitro transcription of ARiBo-tagged RNAs were obtained by inserting double-stranded DNA fragments generated by recursive PCR into the HindIII/ApaI sites of the pARiBo4 plasmid (Bowman et al. 2012; Salvail-Lacoste et al. 2013), and the integrity of each plasmid was verified by sequence analysis. The ARiBo-tagged RNAs were transcribed for $3 \mathrm{~h}$ at $37^{\circ} \mathrm{C}$ using the following reaction conditions: $40 \mathrm{mM}$ HEPES ( $\mathrm{pH}$ 8.0), $50 \mathrm{mM}$ DTT, 0.1\% Triton X100, $1 \mathrm{mM}$ spermidine, $4 \mathrm{mM}$ of each NTP (ATP, CTP, UTP, and GTP), $25 \mathrm{mM} \mathrm{MgCl} 2,60 \mu \mathrm{g} / \mathrm{mL}$ His-tagged T7 RNA polymerase, $3 \mathrm{U} / \mathrm{mL}$ RNAsin ribonuclease inhibitor (Promega), and $80 \mu \mathrm{g} / \mathrm{mL}$ linearized plasmid DNA template (Di Tomasso et al. 2012a). Transcription reactions were stopped by adding $25 \mathrm{mM}$ EDTA $(\mathrm{pH} 8.0)$ and then stored at $-20^{\circ} \mathrm{C}$. Cleavage of the ARiBo tag in the transcription reaction ( $g l m S$ cleavage) and batch-affinity purifications were performed as previously described (Di Tomasso et al. 2014). In vitro transcriptions, glmS cleavage reactions and batchaffinity purifications were monitored by running aliquots on $7.5 \%$ denaturing gels, staining with SYBR-Gold (Invitrogen) and subsequent fluorescence detection on a Bio-Rad ChemiDoc MP Imaging system (Di Tomasso et al. 2014).

\section{ARiBo pull-down assay}

RNA-associated proteins were isolated with a modified version of the ARiBo affinity purification protocol (Di Tomasso et al. 2011, 2012a, 2014). Briefly, $17.5 \mathrm{nmol}$ of $\lambda \mathrm{N}^{+}-\mathrm{L}^{+}$-GST protein was first added to an aliquot of the transcription reaction $(50-200 \mu \mathrm{L})$ containing $3.5 \mathrm{nmol}$ of ARiBo-tagged RNA, and the volume was completed to $400 \mu \mathrm{L}$ with WCE equilibration buffer ( $50 \mathrm{mM}$ HEPES, $\mathrm{pH}$ 7.5, $100 \mathrm{mM} \mathrm{NaCl}$, and $5 \mathrm{mM} \mathrm{MgCl}_{2}$ ). After a 15 -min incubation with rotation at room temperature (RT), the RNA-protein mix was added to a spin-cup column (Pierce) containing $125 \mu \mathrm{L}$ of washed GSH-Sepharose 4B resin (from $163 \mu \mathrm{L}$ of slurry; GE Healthcare) and incubated for another $15 \mathrm{~min}$ at RT. The load eluate was collected by centrifugation for $1 \mathrm{~min}$ at $5000 \mathrm{~g}$. The resin was washed once with $400 \mu \mathrm{L}$ of WCE equilibration buffer. Unless specified otherwise, all washes included incubation for $5 \mathrm{~min}$ at RT with rotation and centrifugation for $1 \mathrm{~min}$ at $5000 \mathrm{~g}$. After this first wash (W1), $300 \mu \mathrm{g}$ of NT2 WCE diluted in WCE equilibration buffer (400 $\mu \mathrm{L}$ total volume) was loaded to the RNA-coupled resin and incubated for $15 \mathrm{~min}$ at $4^{\circ} \mathrm{C}$ with rotation, followed by centrifugation. The resin was then washed once (W2) and rinsed once (six tube inversions followed by centrifugation) with $400 \mu \mathrm{L}$ of WCE equilibration buffer. For the first elution of RNA and associated proteins (E1), the resin was incubated in $400 \mu \mathrm{L}$ of elution buffer $(20 \mathrm{mM}$ Tris [pH 7.6], $10 \mathrm{mM} \mathrm{MgCl}_{2}$, and $1 \mathrm{mM} \mathrm{GlcN6P)}$ for $15 \mathrm{~min}$ at $37^{\circ} \mathrm{C}$ and then for $5 \mathrm{~min}$ at RT prior to centrifugation. For the second elution (E2), the resin was washed once with $400 \mu \mathrm{L}$ of WCE equilibration buffer. Finally, the resin was cleared with $400 \mu \mathrm{L}$ of $2.5 \mathrm{M} \mathrm{NaCl}$. Generally, $10 \%$ aliquots of the load, washes and elution samples (LE, W1, WCE, W2, E1, E2, NaCl) were kept for analysis by denaturing gel electrophoresis (Di Tomasso et al. 2011, 2012a) and Western blot. The rest of the first elution sample was lyophilized for analysis by either Coomassie-stained SDS-PAGE or mass spectrometry. RNA pull-downs were performed in triplicate for all RNAs (the ARiBo-tagged SL-let-7a-1, SL-let-7g, and dlet-7 as well as the mock control) using three different WCE preparations prepared from separate batches of NT2 cells.

\section{Coomassie-stained SDS-PAGE and Western blotting}

A fraction of the first elution sample was precipitated with 25\% (v/v) trichloroacetic acid. The sample was vortexed, incubated for $30 \mathrm{~min}$ on ice, and centrifuged for $20 \mathrm{~min}$ at $16,000 \mathrm{~g}$. The pellet was then washed two times by adding $200 \mu \mathrm{L}$ of acetone and centrifuging $15 \mathrm{~min}$ at $16,000 \mathrm{~g}$. Following the drying of the pellet for $5 \mathrm{~min}$ in a $95^{\circ} \mathrm{C}$ dry bath, the samples were resuspended in Laemmli SDSPAGE sample buffer and run on a $12 \%$ SDS-PAGE. The gel was either stained with Coomassie Blue or transferred to an Immun-Blot PVDF membrane (Bio-Rad) for Western blot analysis using Lin28A (Millipore \#07-1385), Lin28B (Cell Signaling Technology \#4186), IGF2BP1 (Abcam \#ab107205), or nucleolin (Abcam \#ab134164) antibodies. A ChemiDoc MP Imaging system was used for chemiluminescence detection, and band intensities were quantified using the ImageLab software version 4.0.1 (Bio-Rad).

\section{Mass spectrometry data acquisition and analysis}

Proteins eluted following RNA pull-down assays were solubilized in $6 \mathrm{M}$ urea and $100 \mathrm{mM}$ ammonium bicarbonate. Cysteine residues were reduced with $10 \mathrm{mM}$ DTT and alkylated with $55 \mathrm{mM}$ iodoacetamide. The samples were then diluted to reduce the urea concentration to $<1 \mathrm{M}$ and the proteins in-solution digested with trypsin for $16 \mathrm{~h}$ at $37^{\circ} \mathrm{C}$. The reactions were quenched by acidification with trifluoroacetic acid and passed over a C18 spin column (Pierce) to remove nonpolar contaminants, including the RNA and salts. The purified peptides were solubilized in $2 \%$ acetonitrile and $0.5 \%$ acetic acid for online mass spectrometry analysis using an Orbitrap Fusion (Thermo) mass spectrometer. Peptides were trapped on a trapping column and separated on a $75 \mu \mathrm{m} \times 15 \mathrm{~cm}, 2 \mu \mathrm{m}$ Acclaim PepMap reverse phase column (Thermo Scientific) using an UltiMate 3000 RSLCnano HPLC (Thermo Scientific) at a flow rate of $300 \mathrm{~nL} /$ min. Peptides were eluted into the mass spectrometer using a 120min linear gradient from $96 \%$ mobile phase A (0.1\% formic acid) to $55 \%$ mobile phase B ( $80 \%$ acetonitrile and $0.08 \%$ formic acid). Parent full-scan mass spectra were collected in the Orbitrap mass analyzer set to acquire data at 120,000 FWHM resolution; ions were then isolated in the quadrupole mass filter, fragmented within the HCD cell (HCD normalized energy $32 \%$, stepped $\pm 3 \%$ ), and the product ions were analyzed in the ion trap. Monoisotopic precursor selection and dynamic exclusion, with a 30-sec duration and a 10-ppm mass tolerance, were enabled. Proteome Discoverer 1.4 (Thermo) was used to search the data against human proteins from the NCBInr database using SequestHT and MSAmanda (Dorfer et al. 2014). The sequence of the $\lambda \mathrm{N}^{+}-\mathrm{L}^{+}$-GST fusion protein was manually added to the database to allow its identification. The search was limited to tryptic peptides, with maximally two missed cleavages allowed. Cysteine carbamidomethylation was set as a fixed modification; methionine oxidation was allowed as a variable modification. The precursor mass tolerance was $10 \mathrm{ppm}$, and the fragment mass tolerance was 0.6 Da. The Percolator node was used to score and rank peptide matches at a $1 \%$ false discovery 
rate using a reversed database. Proteins were required to be represented by at least two unique peptide sequences. Statistical comparison of the interactomes from biological triplicate experiments was performed using the SAINTexpress algorithm (Teo et al. 2014) based on spectral counts and using default settings. To be considered as interactors, proteins had to be enriched at least twofold as compared with the control samples and have a SAINTexpress score $\geq 0.65$. The selected cutoff score of 0.65 ensures that the interaction has been detected with high probability in at least two of the three replicates.

\section{SUPPLEMENTAL MATERIAL}

Supplemental material is available for this article.

\section{ACKNOWLEDGMENTS}

This work was supported by grants from the Canadian Institutes of Health Research (CIHR) (PPP-122895), the Natural Sciences and Engineering Research Council of Canada (RGPIN-2015-04231), and the Parkinson Society of Canada to P.L. This work was also supported in part by the Intramural Research Program of the National Cancer Institute (L.M.M.J.). The authors thank Luc DesGroseillers, James G. Omichinski, and all members of the Legault laboratory for critical reading of the manuscript.

Received May 13, 2016; accepted August 11, 2016.

\section{REFERENCES}

Abdelmohsen K, Srikantan S, Kang MJ, Gorospe M. 2012. Regulation of senescence by microRNA biogenesis factors. Ageing Res Rev 11: 491-500.

Adachi S, Homoto M, Tanaka R, Hioki Y, Murakami H, Suga H, Matsumoto M, Nakayama KI, Hatta T, Iemura S, et al. 2014. ZFP36L1 and ZFP36L2 control LDLR mRNA stability via the ERK-RSK pathway. Nucleic Acids Res 42: 10037-10049.

Austin RJ, Xia T, Ren J, Takahashi TT, Roberts RW. 2002. Designed arginine-rich RNA-binding peptides with picomolar affinity. $J$ Am Chem Soc 124: 10966-10967.

Baltz AG, Munschauer M, Schwanhausser B, Vasile A, Murakawa Y, Schueler M, Youngs N, Penfold-Brown D, Drew K, Milek M, et al. 2012. The mRNA-bound proteome and its global occupancy profile on protein-coding transcripts. Mol Cell 46: 674-690.

Beckmann BM, Horos R, Fischer B, Castello A, Eichelbaum K, Alleaume AM, Schwarzl T, Curk T, Foehr S, Huber W, et al. 2015. The RNA-binding proteomes from yeast to man harbour conserved enigmRBPs. Nat Commun 6: 10127.

Bell JL, Wachter K, Muhleck B, Pazaitis N, Kohn M, Lederer M, Huttelmaier S. 2013. Insulin-like growth factor 2 mRNA-binding proteins (IGF2BPs): post-transcriptional drivers of cancer progression? Cell Mol Life Sci 70: 2657-2675.

Bowman JC, Azizi B, Lenz TK, Roy P, Williams LD. 2012. Preparation of long templates for RNA in vitro transcription by recursive PCR. Methods Mol Biol 941: 19-41.

Breitkreutz A, Choi H, Sharom JR, Boucher L, Neduva V, Larsen B, Lin ZY, Breitkreutz BJ, Stark C, Liu G, et al. 2010. A global protein kinase and phosphatase interaction network in yeast. Science 328: 1043-1046.

Bussing I, Slack FJ, Grosshans H. 2008. let-7 microRNAs in development, stem cells and cancer. Trends Mol Med 14: 400-409.
Butter F, Scheibe M, Morl M, Mann M. 2009. Unbiased RNA-protein interaction screen by quantitative proteomics. Proc Natl Acad Sci 106: $10626-10631$.

Castello A, Fischer B, Eichelbaum K, Horos R, Beckmann BM, Strein C, Davey NE, Humphreys DT, Preiss T, Steinmetz LM, et al. 2012. Insights into RNA biology from an atlas of mammalian mRNAbinding proteins. Cell 149: 1393-1406.

Chang HM, Triboulet R, Thornton JE, Gregory RI. 2013. A role for the Perlman syndrome exonuclease Dis312 in the Lin28-let-7 pathway. Nature 497: 244-248.

Chen X, Wei S, Ji Y, Guo X, Yang F. 2015. Quantitative proteomics using SILAC: principles, applications, and developments. Proteomics 15: 3175-3192.

Choi H, Liu G, Mellacheruvu D, Tyers M, Gingras AC, Nesvizhskii AI. 2012. Analyzing protein-protein interactions from affinity purification-mass spectrometry data with SAINT. Curr Protoc Bioinformatics 39: 8.15.1-8.15.23.

Connerty P, Ahadi A, Hutvagner G. 2015. RNA binding proteins in the miRNA pathway. Int J Mol Sci 17: pii: E31.

Cox J, Hein MY, Luber CA, Paron I, Nagaraj N, Mann M. 2014. Accurate proteome-wide label-free quantification by delayed normalization and maximal peptide ratio extraction, termed MaxLFQ. Mol Cell Proteomics 13: 2513-2526.

Desjardins A, Yang A, Bouvette J, Omichinski JG, Legault P. 2011. Importance of the NCp7-like domain in the recognition of prelet-7g by the pluripotency factor Lin28. Nucleic Acids Res 40: $1767-1777$.

Desjardins A, Bouvette J, Legault P. 2014. Stepwise assembly of multiple Lin28 proteins on the terminal loop of let-7 miRNA precursors. Nucleic Acids Res 42: 4615-4628.

Di Tomasso G, Lampron P, Dagenais P, Omichinski JG, Legault P. 2011. The ARiBo tag: a reliable tool for affinity purification of RNAs under native conditions. Nucleic Acids Res 39: e18.

Di Tomasso G, Dagenais P, Desjardins A, Rompré-Brodeur A, Delfosse V, Legault P. 2012a. Affinity purification of RNA using an ARiBo tag. Methods Mol Biol 941: 137-155.

Di Tomasso G, Lampron P, Omichinski JG, Legault P. 2012 b. Preparation of $\lambda \mathrm{N}$-GST fusion protein for affinity immobilization of RNA. Methods Mol Biol 941: 123-135.

Di Tomasso G, Salvail-Lacoste A, Bouvette J, Omichinski JG, Legault P. 2014. Affinity purification of in vitro transcribed RNA with homogeneous ends using a 3'-ARiBo tag. Methods Enzymol 549: 49-84.

Dong Y, Yang J, Ye W, Wang Y, Ye C, Weng D, Gao H, Zhang F, Xu Z, Lei Y. 2015. Isolation of endogenously assembled RNA-protein complexes using affinity purification based on streptavidin aptamer S1. Int J Mol Sci 16: 22456-22472.

Dorfer V, Pichler P, Stranzl T, Stadlmann J, Taus T, Winkler S, Mechtler K. 2014. MS Amanda, a universal identification algorithm optimized for high accuracy tandem mass spectra. J Proteome Res 13: 3679-3684.

Faoro C, Ataide SF. 2014. Ribonomic approaches to study the RNAbinding proteome. FEBS Lett 588: 3649-3664.

Gerstberger S, Hafner M, Tuschl T. 2014. A census of human RNAbinding proteins. Nat Rev Genet 15: 829-845.

Graf R, Munschauer M, Mastrobuoni G, Mayr F, Heinemann U, Kempa S, Rajewsky N, Landthaler M. 2013. Identification of LIN28B-bound mRNAs reveals features of target recognition and regulation. RNA Biol 10: 1146-1159.

Ha TY. 2011. MicroRNAs in human diseases: from cancer to cardiovascular disease. Immune Netw 11: 135-154.

Hartmuth K, Urlaub H, Vornlocher HP, Will CL, Gentzel M, Wilm M, Luhrmann R. 2002. Protein composition of human prespliceosomes isolated by a tobramycin affinity-selection method. Proc Natl Acad Sci 99: 16719-16724.

Heo I, Joo C, Cho J, Ha M, Han J, Kim VN. 2008. Lin28 mediates the terminal uridylation of let-7 precursor microRNA. Mol Cell 32: 276-284. 
Heo I, Joo C, Kim YK, Ha M, Yoon MJ, Cho J, Yeom KH, Han J, Kim VN. 2009. TUT4 in concert with Lin28 suppresses microRNA biogenesis through pre-microRNA uridylation. Cell 138: 696-708.

Hogg JR, Collins K. 2007a. Human Y5 RNA specializes a Ro ribonucleoprotein for $5 \mathrm{~S}$ ribosomal RNA quality control. Genes Dev 21: 3067-3072.

Hogg JR, Collins K. 2007b. RNA-based affinity purification reveals 7SK RNPs with distinct composition and regulation. RNA 13: 868-880.

Ishikawa F, Matunis MJ, Dreyfuss G, Cech TR. 1993. Nuclear proteins that bind the pre-mRNA $3^{\prime}$ splice site sequence $\mathrm{r}(\mathrm{UUAG} / \mathrm{G})$ and the human telomeric DNA sequence d(TTAGGG) $)_{n}$. Mol Cell Biol 13: 4301-4310.

Kawahara H, Imai T, Okano H. 2012. MicroRNAs in neural stem cells and neurogenesis. Front Neurosci 6: 30.

Kim YK, Furic L, Parisien M, Major F, DesGroseillers L, Maquat LE. 2007. Staufen 1 regulates diverse classes of mammalian transcripts. EMBO J 26: 2670-2681.

Kotzer-Nevo H, de Lima Alves F, Rappsilber J, Sperling J, Sperling R. 2014. Supraspliceosomes at defined functional states portray the pre-assembled nature of the pre-mRNA processing machine in the cell nucleus. Int J Mol Sci 15: 11637-11664.

Krol J, Loedige I, Filipowicz W. 2010. The widespread regulation of microRNA biogenesis, function and decay. Nat Rev Genet 11: 597-610.

Kwon SC, Yi H, Eichelbaum K, Fohr S, Fischer B, You KT, Castello A, Krijgsveld J, Hentze MW, Kim VN. 2013. The RNA-binding protein repertoire of embryonic stem cells. Nat Struct Mol Biol 20: $1122-1130$

Laver JD, Li X, Ancevicius K, Westwood JT, Smibert CA, Morris QD, Lipshitz HD. 2013. Genome-wide analysis of Staufen-associated mRNAs identifies secondary structures that confer target specificity. Nucleic Acids Res 41: 9438-9460.

Lee HY, Haurwitz RE, Apffel A, Zhou K, Smart B, Wenger CD, Laderman S, Bruhn L, Doudna JA. 2013. RNA-protein analysis using a conditional CRISPR nuclease. Proc Natl Acad Sci 110: 5416-5421.

Leppek K, Stoecklin G. 2014. An optimized streptavidin-binding RNA aptamer for purification of ribonucleoprotein complexes identifies novel ARE-binding proteins. Nucleic Acids Res 42: e13.

McHugh CA, Russell P, Guttman M. 2014. Methods for comprehensive experimental identification of RNA-protein interactions. Genome Biol 15: 203.

Michlewski G, Caceres JF. 2010. RNase-assisted RNA chromatography. RNA 16: 1673-1678.

Michlewski G, Guil S, Semple CA, Caceres JF. 2008. Posttranscriptional regulation of miRNAs harboring conserved terminal loops. Mol Cell 32: 383-393.

Nelson MR, Luo H, Vari HK, Cox BJ, Simmonds AJ, Krause HM, Lipshitz HD, Smibert CA. 2007. A multiprotein complex that mediates translational enhancement in Drosophila. J Biol Chem 282: 34031-34038.

Nguyen LH, Zhu H. 2015. Lin28 and let-7 in cell metabolism and cancer. Transl Pediatr 4: 4-11.

Oeffinger M. 2012. Two steps forward-one step back: advances in affinity purification mass spectrometry of macromolecular complexes. Proteomics 12: 1591-1608.

Panchapakesan SS, Jeng SC, Unrau PJ. 2015. RNA complex purification using high-affinity fluorescent RNA aptamer tags. Ann NY Acad Sci 1341: 149-155.

Patel VL, Mitra S, Harris R, Buxbaum AR, Lionnet T, Brenowitz M, Girvin M, Levy M, Almo SC, Singer RH, et al. 2012. Spatial arrangement of an RNA zipcode identifies mRNAs under post-transcriptional control. Genes Dev 26: 43-53.

Pichiorri F, Palmieri D, De Luca L, Consiglio J, You J, Rocci A, Talabere T, Piovan C, Lagana A, Cascione L, et al. 2013. In vivo NCL targeting affects breast cancer aggressiveness through miRNA regulation. J Exp Med 210: 951-968.
Piskounova E, Viswanathan SR, Janas M, LaPierre RJ, Daley GQ, Sliz P, Gregory RI. 2008. Determinants of microRNA processing inhibition by the developmentally regulated RNA-binding protein Lin28. J Biol Chem 283: 21310-21314.

Rehfeld F, Rohde AM, Nguyen DT, Wulczyn FG. 2015. Lin28 and let-7: ancient milestones on the road from pluripotency to neurogenesis. Cell Tissue Res 359: 145-160.

Ren Z, Veksler-Lublinsky I, Morrissey D, Ambros V. 2016. Staufen negatively modulates microRNA activity in Caenorhabditis elegans. G3 (Bethesda) 6: 1227-1237.

Roush S, Slack FJ. 2008. The let-7 family of microRNAs. Trends Cell Biol 18: $505-516$.

Said N, Rieder R, Hurwitz R, Deckert J, Urlaub H, Vogel J. 2009. In vivo expression and purification of aptamer-tagged small RNA regulators. Nucleic Acids Res 37: e133.

Sakamoto S, Aoki K, Higuchi T, Todaka H, Morisawa K, Tamaki N, Hatano E, Fukushima A, Taniguchi T, Agata Y. 2009. The NF90NF45 complex functions as a negative regulator in the microRNA processing pathway. Mol Cell Biol 29: 3754-3769.

Salvail-Lacoste A, Di Tomasso G, Piette BL, Legault P. 2013. Affinity purification of T7 RNA transcripts with homogeneous ends using ARiBo and CRISPR tags. RNA 19: 1003-1014.

Sandin M, Teleman J, Malmstrom J, Levander F. 2014. Data processing methods and quality control strategies for label-free LC-MS protein quantification. Biochim Biophys Acta 1844: 29-41.

Satoh M, Shaheen VM, Kao PN, Okano T, Shaw M, Yoshida H, Richards HB, Reeves WH. 1999. Autoantibodies define a family of proteins with conserved double-stranded RNA-binding domains as well as DNA binding activity. J Biol Chem 274: 34598-34604.

Skarra DV, Goudreault M, Choi H, Mullin M, Nesvizhskii AI, Gingras AC, Honkanen RE. 2011. Label-free quantitative proteomics and SAINT analysis enable interactome mapping for the human Ser/ Thr protein phosphatase 5. Proteomics 11: 1508-1516.

Slobodin B, Gerst JE. 2010. A novel mRNA affinity purification technique for the identification of interacting proteins and transcripts in ribonucleoprotein complexes. RNA 16: 2277-2290.

Srisawat C, Engelke DR. 2002. RNA affinity tags for purification of RNAs and ribonucleoprotein complexes. Methods 26: 156-161.

Tate S, Larsen B, Bonner R, Gingras AC. 2013. Label-free quantitative proteomics trends for protein-protein interactions. J Proteomics 81: 91-101.

Teo G, Liu G, Zhang J, Nesvizhskii AI, Gingras AC, Choi H. 2014. SAINTexpress: improvements and additional features in significance analysis of INTeractome software. J Proteomics 100: 37-43.

Thornton JE, Gregory RI. 2012. How does Lin28 let-7 control development and disease? Trends Cell Biol 22: 474-482.

Triboulet R, Pirouz M, Gregory RI. 2015. A single let-7 microRNA bypasses LIN28-mediated repression. Cell Rep 13: 260-266.

van Kouwenhove M, Kedde M, Agami R. 2011. MicroRNA regulation by RNA-binding proteins and its implications for cancer. Nat Rev Cancer 11: 644-656.

Vasudevan S, Steitz JA. 2007. AU-rich-element-mediated upregulation of translation by FXR1 and Argonaute 2. Cell 128: 1105-1118.

Viswanathan SR, Daley GQ. 2010. Lin28: a microRNA regulator with a macro role. Cell 140: 445-449.

Viswanathan SR, Daley GQ, Gregory RI. 2008. Selective blockade of microRNA processing by Lin28. Science 320: 97-100.

Weidensdorfer D, Stohr N, Baude A, Lederer M, Kohn M, Schierhorn A, Buchmeier S, Wahle E, Huttelmaier S. 2009. Control of c-myc mRNA stability by IGF2BP1-associated cytoplasmic RNPs. RNA 15: $104-115$.

Wickham L, Duchaine T, Luo M, Nabi IR, DesGroseillers L. 1999. Mammalian staufen is a double-stranded-RNA- and tubulin-binding protein which localizes to the rough endoplasmic reticulum. Mol Cell Biol 19: 2220-2230. 

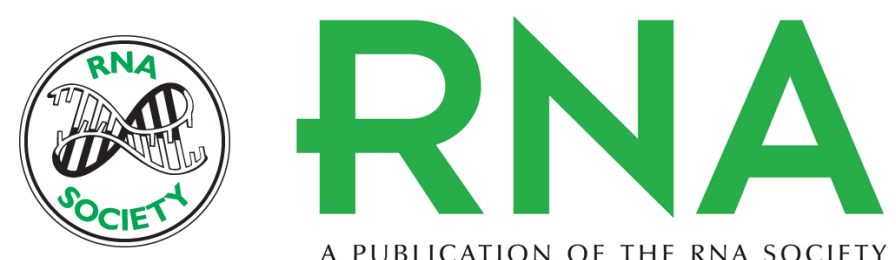

A PUBLICATION OF THE RNA SOCIETY

\section{ARiBo pull-down for riboproteomic studies based on label-free quantitative mass spectrometry}

Geneviève Di Tomasso, Lisa M. Miller Jenkins and Pascale Legault

RNA 2016 22: 1760-1770 originally published online September 22, 2016

Access the most recent version at doi:10.1261/rna.057513.116

\section{Supplemental http://rnajournal.cshlp.org/content/suppl/2016/09/22/rna.057513.116.DC1 \\ Material}

References This article cites 73 articles, 22 of which can be accessed free at: http://rnajournal.cshlp.org/content/22/11/1760.full.html\#ref-list-1

Open Access Freely available online through the RNA Open Access option.

Creative This article, published in RNA, is available under a Creative Commons License Commons (Attribution-NonCommercial 4.0 International), as described at License http://creativecommons.org/licenses/by-nc/4.0/.

Email Alerting Receive free email alerts when new articles cite this article - sign up in the box at the Service top right corner of the article or click here.

To subscribe to RNA go to:

http://rnajournal.cshlp.org/subscriptions 